\title{
The South China Sea
}

\author{
Troubled Waters in \\ China-U.S. Relations
}

Cai Penghong

\begin{abstract}
Similar to his foreign policy and strategic thinking, President Trump's South China Sea policy features strong uncertainty. The new president is keen on enhancing U.S. military strength, but often uses "suspense" to achieve better deals on the negotiation table. Whether the practice can be directly linked to the rebalancing strategy is uncertain, but it can be said that the Trump administration is seeking peace through stronger military power, which will exert complex impact on the security situation of the South China Sea as well as the rest of the Asia-Pacific region. President Trump believes that the United States should consolidate its maritime supremacy in the Asia-Pacific, yet seeking confrontation and conflicts is by no means a policy option for the United States to maintain its regional hegemony. In comparison, China's approach to resolving disputes and the security dilemma with the United States is to seek common ground while shelving disputes. Both countries should try to enhance their mutual understanding on the South China Sea issue for sustainable development of China-U.S. relations.
\end{abstract}

Keywords: China-U.S. relations; South China Sea disputes; maritime security; Asia-Pacific strategy; U.S. supremacy.

Cai Penghong is Senior Fellow at the Center for Asia-Pacific Studies, Shanghai Institutes for International Studies (SIIS). His mailing address is 195-15 Tianlin Road, Shanghai 200233, China. He can also be reached at caipenghong@siis.org.cn.

(c) 2017 World Century Publishing Corporation and Shanghai Institutes for International Studies China Quarterly of International Strategic Studies, Vol. 3, No. 2, 283-298

DOI: $10.1142 / S 2377740017500130$ 
The South China Sea (SCS) has increasingly become a hot issue in ChinaU.S. relations. Since 2015, American warships have regularly conducted freedom of navigation operations (FONOPs) and even sailed within 12 nautical miles $(12 \mathrm{~nm})$ of China's islands. The Trump administration has temporarily reduced the number of FONOPs but will very likely continue to exert security pressure on China. As Secretary of State nominee Rex Tillerson said on January 11, 2017, "China should not be allowed access to islands it has built in the contested South China Sea." Arguably, the new administration is beginning to draw a "red line" for China, signaling "a sharp departure from years of cautious U.S. handling of China's assertive pursuit of territory claims in Asia." ${ }^{1}$ Over time, China's territorial disputes with some states within the Association of Southeast Asian Nations (ASEAN) have been replaced by its geopolitical competition with the United States at its doorsteps.

This article analyzes the evolution and implications of the SCS issue to the China-U.S. relationship, and projects how the security tensions in the South China Sea might change under the Trump presidency. It consists of four sections: the first reviews the SCS issue in the development of China-U.S. relations by the end of the Cold War; the second section analyzes China's SCS policy and how the changes in the U.S. policy have affected the bilateral relationship; the third addresses the SCS policy of the Trump administration; and the fourth section explores the options for both countries to resolve the SCS issue, so as to stabilize and further promote their bilateral relationship.

\section{The South China Sea as a Testing Ground for China-U.S. Relations}

The South China Sea has a special position in the development of ChinaU.S. relations despite the fact that it is almost 8,000 miles away from the west coast of the United States. Distance has never stopped the United States from seeking presence in the region; in fact, it is Americans' earliest commercial navigation route to China. Around the years of American

\footnotetext{
${ }^{1}$ David Brunnstrom and Matt Spetalnick, "Trump White House Vows to Stop China Taking South China Sea Islands," Reuters, January 24, 2017, https://www.yahoo.com/news/ u-says-prevent-china-taking-over-territory-international-213213672.html.
} 
revolution, Chinese products such as tea, willow pattern porcelains, and flowery silks were shipped from southern China through the South China Sea to the young United States. ${ }^{2}$ Although backward shipbuilding technology weakened ocean-shipping capabilities in the 18th and 19th centuries, navigating difficulties were overcome and ocean transportation played an extraordinary role in spurring trade and people-to-people exchanges between China and the United States. One might even presume that without "smooth" waters like the South China Sea, the Boston Tea Party would have never occurred, because the tea dumped into the Boston Harbor in 1773 had come from China. ${ }^{3}$ Landmarks of the trade relations between both countries are listed in Table 1 .

Trade policy and activities are inseparable from politics. Free trade and freedom of navigation upheld by the United States in the South China Sea were adopted as a government policy over a century ago. Since then, the United States has made various efforts to expand its influence into the South China Sea.

The U.S. victory in the Spanish-American War allowed it to take over colonial rule of the Philippines from Spain in 1898, thus beginning a presence in the South China Sea. As former U.S. Secretary of State Daniel Webster remarked, what the United States wanted was to have trade exchanges with China; it did not covet Chinese territory like the British, who occupied Hong Kong; thousands of miles apart, the United States and China were "maritime neighbors." ${ }^{4}$ With the rising ambition and

Commercial interest has been the U.S.' top concern in its military engagement in the South China Sea. maritime power of the Japanese empire, however, geopolitical significance emerged on the seascape of the South China Sea, and the United States had to confront Japan brutally in the region during World War II.

After the Pearl Harbor attack in 1941, China and the United States allied against

\footnotetext{
${ }^{2}$ Beside those products, the tea that was tossed into Boston Harbor in 1773 had been actually shipped out of southern China through waters which were supposed to include the South China Sea. See John Pomfret, The Beautiful Country and the Middle Kingdom (New York: Henry Holt and Company Publishers, 2016), p. 11.
}

${ }^{3}$ John Pomfret, The Beautiful Country and the Middle Kingdom.

${ }^{4}$ John Pomfret, The Beautiful Country and the Middle Kingdom, p. 36. 
Table 1. Timeline of China-U.S. Trade.

\begin{tabular}{|c|c|}
\hline 1773 & The tea dumped into the Boston Harbor had been shipped from Fujian, China. \\
\hline 1784 & $\begin{array}{l}\text { China-U.S. formal trade opened with a New York ship, Empress of China, } \\
\text { sailing across the Indian Ocean and South China Sea, to Guangzhou } \\
\text { (Canton), China. }\end{array}$ \\
\hline 1787 & A Boston ship, Columbia, carried sea-otter pelts to Guangzhou. \\
\hline 1805 & A Baltimore ship, Entan, carried opium to Guangzhou. \\
\hline $1840-42$ & The Opium War. \\
\hline 1844 & The Treaty of Wangxia granted the U.S. trading rights in China. \\
\hline 1898 & The U.S. defeated Spain and took over colonial rule in the Philippines. \\
\hline 1899-1900 & $\begin{array}{l}\text { The U.S. persuaded China to keep ports open to Western trade from all } \\
\text { nations. }\end{array}$ \\
\hline 1945 & $\begin{array}{l}\text { American B-25s bombed Taiping Island (Itu Aba) and Yongxing (Woody Is- } \\
\text { land) in the SCS, which were under Japanese occupation during WWII. }\end{array}$ \\
\hline 1950 & $\begin{array}{l}\text { As the Korean War began, China and the U.S. broke all relations, while the } \\
\text { latter conducted comprehensive trade sanctions against the former. }\end{array}$ \\
\hline 1972 & China-U.S. trade resumed. \\
\hline 1979 & China and the U.S. resumed diplomatic relations. \\
\hline 2016 & China-U.S. trade reached US $\$ 620$ billion. \\
\hline
\end{tabular}

Sources: Author's compilation based on the following materials: (1) John Pomfret, The Beautiful Country and the Middle Kingdom; (2) Stein Tonnesson, The South China Sea in the Age of European Decline (Oslo: International Peace Research Institute, 2006); (3) Bill Hayton, "Calm and Storm: the South China Sea after the Second World War," Center for Strategic and International Studies, August 13, 2015, https://amti.csis.org/calm-and-stormthe-South-China-Sea-After-The-Second-World-War//\#_FTN16; and (4) "Two Hundred Years of U.S. Trade with China (1784-1984)," Asia for Educators, http://afe.easia.columbia.edu/ special/china_1750_us.htm.

Japan in the South China Sea as well as on Chinese soil. According to Admiral Chester W. Nimitz, Commander in Chief of the United States Pacific Fleet, the U.S. navy carried out huge operations targeting the Japanese navy, beginning from 1942 to August 1945 in the region. For example, American naval forces destroyed 1,018 Japanese planes in the South China Sea from October 10 to $20,1944 .{ }^{5}$ The American naval operations did not end until the Japanese surrendered. In the Cairo Declaration (1943) and Potsdam Proclamation (1945), the United States and allied powers called for the

${ }^{5}$ Chester W. Nimitz and James M. Steele, Command Summary of Fleet Admiral Chester W. Nimitz, USN, Nimitz "Graybook," 7 December 1941-31 August 1945 (Newport: United States Naval War College, 2013), pp. 1898 and 2015. 
Japanese to surrender and that all Chinese islands and features seized by Japan be returned to China. Therefore, China resumed its sovereignty over Taiwan, Penghu Islands, Xisha (Paracel) Islands and Nansha (Spratly) Islands. Notably, As Mr. Dai Bingguo, former State Councilor of China, said on a thinktank dialogue between China and the United States,

\begin{abstract}
China's actions to restore the islands were supported by General Douglas McArthur. China's military and government personnel were ferried by U.S.-provided military vessels to Xisha and Nansha Islands to hold the restoration ceremony. After that, the U.S. filed applications to Chinese authorities on Taiwan to conduct geodetic survey in some of Nansha Islands on many occasions. $^{6}$
\end{abstract}

Unfortunately, the Cold War and the bipolar system made China a rival to the United States, and Americans tried to build a "breakwater wall" along the first island chain extending from Northeast Asia to the South China Sea. To fence off the communist forces in Southeast Asia, the United States set up a military organization, the Southeast Asian Treaty Organization (SEATO), in 1954, whose member countries like the Philippines and Thailand were coastal countries of the South China Sea. Undoubtedly, "U.S. officials believed Southeast Asia to be a crucial frontier in the fight against communist expansion, so it viewed SEATO as essential to its global Cold War policy of containment." 7 The South China Sea thus became a frontline or the southernmost part of the first island chain for the United States to contain China.

Nevertheless, prior to the 2000s, the United States had maintained a neutral position on the territorial disputes among regional countries. For example, during the Vietnam War, U.S. bombers deliberately kept away from Xisha Islands on the way to bomb North Vietnam in case China felt offended. As another example, although the Nixon administration was

6"Speech by Dai Bingguo at China-U.S. Dialogue on South China Sea Between Chinese and U.S. Think Tanks," Chinese Foreign Ministry, July 5, 2016, http://www.fmprc.gov.cn/ mfa_eng/wjdt_665385/zyjh_665391/t1377747.shtml.

${ }^{7}$ Southeast Asia Treaty Organization (SEATO), 1954, https://history.state.gov/milestones/1953-1960/seato. 
notified that a naval skirmish between China and South Vietnam (then an American ally) occurred in the Xisha waters in January 1974, it took no military action to support the Saigon regime. Likewise, the United States remained neutral about the naval skirmish between China and Vietnam in waters near China's Chigua Jiao (Johnson South Reef) on March 14, 1988, when China defeated Vietnam and restored management over this reef and five other features. Regarding the Meiji Jiao (Mischief Reef) incident in 1995, the U.S. State Department also made a statement that the United States maintained a neutral stand, but that freedom of navigation in the South China Sea should be secured for trade.

Historical records reveal that since economic interests are the top concern for the United States, it would desire a normal trade channel and safe sea-lanes in the South China Sea, which explains its policy of neutrality. In other words, the diplomatic and military leverage the United States has gained over the past century is mainly to serve its economic interest. Such background is essential for analyzing potential conflicts and cooperation between China and the United States before the maritime delimitations are fulfilled in the South China Sea among regional disputants.

\section{China's Firm Stance on the South China Sea Issue}

To China, its sovereignty over the South China Sea islands and their adjacent waters is indisputable. Since the People's Republic was founded in 1949, Beijing has tried every means to address the question of demarcating borders with its land and maritime neighboring countries, especially those maritime countries in the South China Sea, which is a sensitive and tough issue not only for domestic politics but also for foreign relations with the related countries. It has taken Beijing more than six decades to deliberate and improve its South China Sea policy. Domestically, the key issue is whether Beijing can withdraw from the claims made by all the administrations since the Qing Dynasty more than a century ago; internationally, any new policy on the South China Sea would exert significant impact on China's relationship, not only with its maritime neighbors, but also with others like the United States and Japan, for safe sea-lanes in the Pacific and Indian Oceans; in particular crosslanes passing the South China Sea, are vital to their trade. With all these considerations, the Chinese government has been very prudent in 
formulating its South China Sea policy since the early 1950s, which manifests the following features.

First, the policy needs to uphold the political legitimacy of the Chinese government. Claiming territorial sovereignty with a policy statement at least as strong as previous regimes was a necessity for Beijing during the early years of the People's Republic. Thus, Chinese Foreign Minister Zhou Enlai issued the Declaration on the Draft Peace Treaty and affirmed China's sovereignty over islands in the South China Sea as early as 1951, which stated that "the Chinese government of the day had taken over those islands" and that the rightful sovereignty of the People's Republic "shall remain intact." ${ }^{8}$

China holds both historical and legal justifications for its South China Sea

claims.

Second, the establishment of domestic law helps fulfill the ownership of territorial lands, islands, rocks, and reefs in the South China Sea. The course of formulating relevant law has come a long way from the 1950s till the present time. In September 1958, China promulgated the Declaration of the Government of the People's Republic of China on China's Territorial Sea, the first legal document on China's maritime sovereignty and rights issued by the new government. The Declaration applies a 12 nautical mile $(12 \mathrm{~nm})$ breath rule for its territorial waters - not only to the mainland and coastal islands, but also to offshore islands in the South China Sea including the four island groups - Dongsha, Nansha, Xisha, and Zhongsha islands. Chinese sovereign rights over those islands and features in the South China Sea were thus reaffirmed. Later, the Chinese government began to issue geographical names on the SCS islands. In April 1983, the China Committee on Geographical Names was authorized to publish 287 standard geographical names for SCS islands, which included the official name of the Huangyan Island (Scarborough Shoal).

China also established its Continental Shelf and Exclusive Economic Zones (EEZs) to confirm its sovereign and maritime rights. The Law of the

8“Foreign Minister Zhou Enlai's Declaration on the Draft Peace Treaty with Japan by the U.S. and the UK and on the San Francisco Conference [周恩来外长关于美英对日和约草案及旧金山会议的声明], Chinese Foreign Ministry, August 15, 1951, http://www.mfa.gov.cn/nanhai/chn/zcfg/t1367520.htm. 
People's Republic of China Concerning the Territorial Sea and the Contiguous Zone enacted in 1992 reaffirms that the four island groups in the South China Sea are within the land territory of China. This law also stipulates that $12 \mathrm{~nm}$ territorial sea should be applied to the four island groups and that straight baselines should be used for measuring the breadth of the territorial sea. Although the base points for measuring the territorial sea have not been set, those on the Xisha Islands were promulgated in 1996. The 1998 Law of the People's Republic of China on EEZs and Continental Shelf further reaffirmed China's territorial sovereignty and maritime rights. According to Article 14, the Law does not prejudice China's "historic rights."

In opposition to the notes submitted by Vietnam and Malaysia (jointly) and Vietnam (individually) to the Commission on the Limits of the Continental Shelf concerning delimitation of the South China Sea, China submitted two Notes Verbales to the United Nations (UN) Secretary General in 2009, including a map of the waters, islands and other features within the nine-dash line. The Notes declared "indisputable sovereignty over the islands in the South China Sea and the adjacent waters" and stated that China "enjoys sovereign rights and jurisdiction over the relevant waters as well as the seabed and subsoil thereof." ${ }^{\prime 9}$ Thus, it was not surprising that China fiercely rejected the decision by the Permanent Court of Arbitration in the Hague on July 12, 2016. As existing Chinese law and regulations have been insufficient in protecting China's maritime rights and interests, a basic maritime law is being drafted on the national level and could be applied in the foreseeable future. ${ }^{10}$

Third, China has welcomed the neutral stance of countries outside the territorial disputes and would resist any biased or aggravating action from them. In fact, the Chinese government has made increasing efforts to implement the 2002 Declaration of Conducts of Parties in the South China Sea (DOC), so as to maintain peace and stability in the region before a final

9"Statement of the Government of the People's Republic of China on China's Territorial Sovereignty and Maritime Rights and Interests in the South China Sea," Chinese Foreign Ministry, July 12, 2016, http://www.fmprc.gov.cn/nanhai/eng/snhwtlcwj_1/t1379493.htm.

10 “China to Make Maritime Law in Five Years," Xinhua News, March 5, 2016, http:// news.xinhuanet.com/english/2016-03/05/c_135157406.htm. 
resolution is achieved. But Washington surprised Beijing with its new policy in favor of other claimants against China at ASEAN Foreign Ministers' Meeting in Hanoi in July 2010, when Secretary of State Hillary Clinton announced that the United States rejected China's claims and wanted to play the role of an arbitrator. The U.S. government and thinktanks also began to sponsor seminars or conferences on the issue. Since then, China-U.S. relations have become inseparable from the complex issues concerning the South China Sea.

\section{A Sea of Growing Geostrategic Competition}

Hillary Clinton's remarks at the 2010 ASEAN meeting could been seen as a U.S. response to China's rapidly rising economic power and regional influence. Since the outbreak of the global financial crisis in 2008, there has been a prevailing, though not necessarily correct, thought in the United States - among both elites and the public - that the country is on an inevitable decline and that its superpower status might soon be replaced by China.

Under such apprehension, Washington sees China rapidly modernizing every aspect of its maritime power, such as its naval surface fleet, submarines, aircrafts, missiles, radar capabilities, and coast guards. It also sees China developing high-end technologies intended to weaken U.S. military supremacy and to prepare for contingencies in the South China Sea. ${ }^{11}$ Since 2010, Washington has forsaken its neutral stance and increasingly supported other claimants in the SCS disputes against China, which escalates the strategic competition among major powers in the

The South China Sea provides a new ground for Sino-U.S. strategic competition. region.

To many political elites in Washington, China has been an obstacle to the rules-based order in the South China Sea. On 2014 West Point Commencement, President Obama implied China as an aggressor: "Regional aggression that goes unchecked — whether

${ }^{11}$ U.S. Department of Defense, Asia-Pacific Maritime Security Strategy 2015 (Washington, D.C.: U.S. Department of Defense, 2015). 
in southern Ukraine or the South China Sea - will ultimately impact our allies and could draw in our military." ${ }^{\prime 2}$ During the second term of the Obama administration, U.S. navy ships carried out more FONOPs in the South China Sea, sometimes even sailing within $12 \mathrm{~nm}$ of China's reefs and rocks in the Nansha and Xisha Islands.

Although President Trump has not publicly announced a South China Sea policy, one policy report revealed on his campaign website indicates that he may order stronger U.S. military deployment in the South China Sea to counter Chinese "adventurism." As the campaign website says, "A strong military presence will be a clear signal to China and other nations in Asia and around the world that America is back in the global leadership business." ${ }^{13}$ Core security teams of both the Obama and Trump administrations hold that China has intruded into the Nansha Islands. At the power transition conference held at the United States Institute for Peace on January 10, 2017, then National Security Advisor Susan Rice accused China of violating the current international order with its behavior in the South China Sea. ${ }^{14}$ On the following day, Rex Tillerson made similar remarks at a congressional hearing, denouncing China's actions on "non-negotiable sovereignty" regarding the Nansha Islands and surrounding areas. ${ }^{15}$

As solemn as it seems, the U.S. criticism is widely interpreted by Chinese as a pretext for maintaining the U.S. maritime supremacy and the U.S.-dominated regional security order. Chinese President Xi Jinping has

${ }^{12}$ Barack Obama, Commencement Address at the United States Military Academy in West Point, New York, May 28, 2014, https://www.gpo.gov/fdsys/pkg/DCPD-201400405/ pdf/DCPD-201400405.pdf.

${ }^{13}$ Ralph Jennings, “Trump Expected to Take Tough but Brief Action in South China Sea," VOA, November 14, 2016, http://www.voanews.com/a/trump-expected-to-take-toughbut-brief-action-in-asian-maritime-dispute/3594889.html.

14 “National Security Advisor Susan E. Rice's Remarks at 'Passing the Baton' Conference," Africa Newswire, January 10, 2017, http://africanewswire.za.com/nationalsecurity-advisor-susan-e-rices-remarks-at-passing-the-baton-conference/.

${ }^{15}$ Simon Denyer, "Is Trump ready for war in the South China Sea, or is his team just (not being clear?), Washington Post, January 24, 2017, https://www.washingtonpost.com/ news/worldviews/wp/2017/01/24/is-trump-ready-for-war-in-the-south-china-sea-or-is-histeam-just-not-being-clear/?utm_term=.5ebb3e4f13ae. 
many times reiterated that China will firmly safeguard its sovereignty and rights in the South China Sea and take all efforts to maintain peace and stability of the region, while trying its best to resolve disputes peacefully through direct consultation and negotiation with other countries concerned. The Chinese government has also reaffirmed that it respects the freedom of navigation and overflight entitled to all countries by international law. Thus, it is China's hope that the United States does not take sides in disputes regarding sovereignty and territory and "play a constructive role in safeguarding the peace and stability of the South China Sea." ${ }^{\prime 16}$

Meanwhile, China has taken more concrete measures to substantiate its sovereignty over the islands and reefs in the South China Sea. Above all, China has begun to carry out patrols in the region with Coast Guard ships and militia vessels, including fishing boats. As some American scholars observe, Chinese militia with Coast Guard ships has become China's “Third Sea Force" in projecting its growing maritime power. ${ }^{17}$ Indeed, it is a maritime practice with Chinese characteristics: using non-naval forces to maintain peace and stability and inspecting other countries' vessels entering territorial waters of Chinese SCS islands.

The U.S. engagement in the SCS issue has triggered stronger resolve and harsher actions from China.

Moreover, China has been enhancing its military support for fishing and other activities in the South China Sea. When President Xi boarded a fishermen's boat that had returned from the South China Sea during his visit to Qionghai, Hainan, on April 11, 2013, he expressed his wish that the South China Sea can be safe for fishing

${ }^{16}$ “Xi Jinping Meets with President Barack Obama of US," Chinese Foreign Ministry, September 3, 2016, http://www.fmprc.gov.cn/mfa_eng/topics_665678/XJPCXBZCESGJTLD RDSYCFHJCXYGHD/t1395073.shtml.

${ }^{17}$ Andrew S. Erickson, “The South China Sea's Third Force: Understanding and Countering China's Maritime Militia," Testimony before the House Armed Services Committee Seapower and Projection Forces Subcommittee, Hearing on Seapower and Projection Forces in the South China Sea, Washington, D.C., September 21, 2016, http:// docs.house.gov/meetings/AS/AS28/20160921/105309/HHRG-114-AS28-Wstate-EricksonPhDA-20160921.pdf. 
activities and wanted the maritime militia to support the government's land reclamation activities. ${ }^{18}$ Apparently, such military support is crucial to safeguarding China's maritime rights and interests in the South China Sea.

The Chinese government has also carried out more routine military exercises including joint navy and air maneuvers in the South China Sea, sending clear signals that it will spare no efforts to protect its sovereignty, maritime rights and interests. To China, the U.S. FONOPs symbolize a sort of military adventurism, as American naval destroyers and bombers risk intruding into $12 \mathrm{~nm}$ of Chinese territorial waters and air space. In response, China launched a large-scale navy exercise in the South China Sea in early July 2016 under the close watch of an American carrier battle group nearby, indicating strong Chinese determination to resist intrusion of the U.S. navy and air force into its territorial waters and air space.

Furthermore, China has begun to build more civilian and paramilitary facilities on its islands and reefs in the South China Sea, demonstrating its resolution to safeguard its sovereignty and maritime rights against opposition from other countries. Those facilities include two lighthouses erected on the Huanyang Jiao (Cuarteron Reef) and Chigua Jiao, three airstrips with about 3-km-long runways, radar and communication gears, and dredged deep ports on the Yongshu Jiao (Fiery Cross Reef), Zhubi Jiao (Subi Reef) and Meiji Jiao (Mischief Reef) in the Nansha Islands. Despite the widespread rhetoric of China "militarizing the South China Sea," those facilities will certainly serve coastal nations in the region and passing vessels from around the world.

\section{Trump's SCS Policy and China's Countermeasures}

As part of the maritime domain, the South China Sea has become a new field for strategic competition between China and the United States. For all the common interests between both countries, issues of contention and a security dilemma obviously exist. The Obama administration took many

${ }^{18}$ An Baijie, “President Pays Visit to Hainan Fishermen," China Daily, April 11, 2013, http://usa.chinadaily.com.cn/china/2013-04/11/content_16391593.htm. 
measures to strengthen the U.S. military position in the Asia-Pacific, especially the SCS region, in order to balance China's expanding naval power. In large part to cope with the U.S. pressure, China proposed the "Belt and Road" initiative to ease security tensions by enhancing economic and people-to-people ties among regional countries.

After President Trump assumed office, many believe that the new U.S. administration will adopt an even harsher South China Sea policy with regard to China, for he seems to share the mainstream perception of the political and intellectual elites in Washington about strategic competition with China. So far, it has been difficult to gain an insight into President Trump's strategic mindset; uncertainty remains his most salient characteristic because he favors "suspense" in negotiating deals with his counterparts, whether U.S. allies or competitors. Nevertheless, President Trump's SCS policy is very likely to bear the following features.

\section{Trump's tough}

military posture in the South China Sea

may cause lose-lose

conflicts with China.

First, the Trump administration is expected to further consolidate the supremacy of U.S. military power and strengthen military deployment in the SCS region. On his inauguration day, the White House website published the new president's six policy priorities. To him, military strength seems to be almighty, without which there would be no peace for the United States. As

President Trump remarked,

History shows that when America is not prepared is when the danger is greatest. We want to deter, avoid and prevent conflict through our unquestioned military strength. Under Barack Obama and Hillary Clinton, defense spending is on track to fall to its lowest level as a share of the economy since the end of World War II.......(And thus) I will ask Congress to fully eliminate the defense sequester and will submit a new budget to rebuild our military...... 19

${ }^{19}$ Washington Examiner Staff, “Text: Trump's Remarks on Military Readiness," Washington Examiner, September 7, 2016, http://www.washingtonexaminer.com/text-trumpsremarks-on-military-readiness/article/2601173. 
With this mindset, the Trump administration may very likely continue strengthening the U.S. hard power and military presence in the Asia-Pacific, including the South China Sea.

Secondly, President Trump's South China Sea policy is ultimately an integral part of his maritime strategy. As he believes in U.S. military supremacy, especially in the Asia-Pacific, how to achieve and maintain that goal is worth some discussion. From President Trump's remarks up to the present, it can be inferred that his approach has four major elements: the first is to increase the number of naval personnel; the second is to build more naval vessels - as he said, the United States would build a 350-ship Navy up from 276 ships in service today; ${ }^{20}$ the third is to upgrade the quality of naval facilitates and develop a state-of-the-art missile defense system on naval ships; and the fourth is to continue, if not increase, aircraftcarriers patrols in the West Pacific as well as FONOPs in the South China Sea.

Finally, President Trump's maritime strategy is very likely to be based on continued forward deployment of the military and enhanced security relations with the United States' allies and partners in the Asia-Pacific. Abandoning the previous U.S. maritime strategy that emphasized cooperation with regional countries in both traditional and non-traditional arenas, the Trump administration may adopt a new strategy inclined toward addressing acute maritime conflicts with state-actors in the region, not least China, while trying to enhance security ties with such allies and partners as the Philippines, Thailand and India.

However, after the Xi-Trump meeting at Mar-a-Lago, Florida in early April 2017, the Trump administration appears to be taking a neutral stand in SCS territorial disputes - at least for the time being. Before the low-key patrol of USS Dewey in the South China Sea on May 24, 2017, the Trump administration had suspended FONOPs in the region altogether. This hiatus, however, should not detract from the fact that the U.S. Congress consecutively approved National Defense Authorization Acts for Fiscal Years 2016 and 2017. The Act for 2016 set up a South China Sea Initiative authorizing the Secretary of Defense with the concurrence of the Secretary of State to provide assistance to national military or other security forces of such allies and security partners as Indonesia, Malaysia, the Philippines,

${ }^{20}$ Ibid. 
Thailand, and Vietnam; the Act for 2017 continues the Initiative but only changes the name into Southeast Asia Maritime Security Initiative. ${ }^{21}$ Therefore, it is not surprising if the Trump administration issues a new South China Sea policy targeted harshly at China when the more urgent issues of North Korean nuclear/missile tests and the U.S. trade deficit are more or less settled. After all, as long as China keeps rising, the United States would feel its dominance of the regional maritime order threatened, and a struggle for power and influence will very likely proceed.

The bilateral relationship between China and the United States is a critical factor for the security situation of the South China Sea as well as the whole Asia-Pacific. President Trump's sober and neutral stance on the SCS issue should be applauded, which benefits the region at least for now despite the uncertain future. Again, China's notion of "seeking common interests while shelving disputes" will continue to serve as a basic principle for regional countries to work together in maintaining peace and stability in the South China Sea. For China and the United States, the two giants in the region, the following policy options need to be considered:

(1) Bilateral cooperation in the South China Sea must follow the principles of non-conflict, non-confrontation, mutual respect, and win-win cooperation. As President Xi told President-elect Trump in a phone call on November 14, 2017, "I attach great importance to China-U.S. relations and am ready to work with the U.S. side to carry forward bilateral ties and to better benefit the two peoples and the rest of the world." ${ }^{22}$ His remarks should be applied not only to the general China-U.S. relationship, but also to their cooperation in the South China Sea in particular.

(2) Non-traditional maritime issues in the South China Sea should be considered as a new field for China-U.S. collaboration. Both governments have agreed to advance maritime cooperation to address ocean acidification, unsustainable fishing, marine pollution, and marine litter, among other things. Yet such cooperation programs have not extended to the South China Sea. In the future, not only should both countries

${ }^{21} 114$ th Congress, House of Representatives, National Defense Authorization Act for Fiscal Year 2017, http://docs.house.gov/billsthisweek/20161128/CRPT-114HRPT-S2943.pdf.

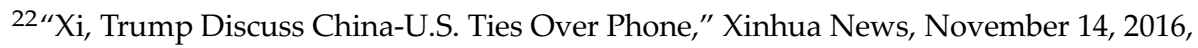
http://news.xinhuanet.com/english/2016-11/14/c_135828429.htm. 
enhance cooperation in those fields, but maritime disaster reduction as well as search and rescue operations in the region should also be included.

(3) Exchanges on maritime issues related to the South China Sea need to be encouraged on all dimensions. Apart from the existing cooperative activities between governmental agencies like coast guards and custom offices, both sides should strengthen their communication and exchanges in marine scientific research and ocean observation, as well as among various thinktanks.

(4) Both countries should consider further cooperation in combating maritime terrorism in the South China Sea and even in the Indian Ocean. President Trump has put anti-terrorism at the top of his defense agenda, and China can do more to work with the Trump administration to battle terrorism in Southeast Asia, which will not only help foster stronger security ties between China and the United States, but also contribute to regional peace and stability for the common good of all countries. 